\title{
Beyhude Ömrüm Hikâyesinde Kahramanın Suyun Ardındaki Yolculuğu
}

\author{
MEHMET GÜNEȘ*
}

\begin{abstract}
ÖZ
Su kültü, Türk kültüründe çok eski dönemlerde var olup temeli “yer-su” inanışına dayanır. Kültlerle ilgili inanış ve uygulamalara, sözlü anlatım ürünlerinde temel motifler olarak rastlanır. Modern Türk anlatılarında da suyun, motif/izlek olarak metnin kurgusunda işlevsel olarak kullanıldığ1 görülür. Mustafa Kutlu'nun Beyhude Ömrüm hikâyesinde su motifi, hikâyenin kurgusunda oldukça işlevseldir. Hikâyede kahraman "Islak Kaya" nın varlığından yıllardır haberdar olmakla birlikte, kayanın içinde suyu barındırdığını fark edince hedef belirler. Masal kahramanları gibi hedefine ulaşmak için plan yapar. Onun Islak Kaya'yı yarıp içindeki suyu çıkarması masal kahramanlarının yolculuğunu andırır. Bu esnada bazı engellerle karşılaşır, aklını kullanarak ve yönlendiricilerin de destekleriyle hedefine ulaşır. Islak Kaya'nın öneminin fark edilmesiyle kaderine terk edilen kıraç topraklar, aslına uygun olarak kullanılıp yeniden doğar. Kutlu hakkında daha önce yapılan çalışmalarda Beyhude Ömrüm hikâyesindeki folklorik unsurlara değinilmemiştir. Bu hikâye hakkında özgün bir çalışma yapan Hatice Altunkaya, metni sadece Greimas'in "Eyleyenler” modeline göre incelemiştir. Bu yazıda ise Beyhude Ömrüm hikâyesindeki kahramanın suyun ardındaki mücadelesinin masal kahramanlarıla benzerlik ve farklılıkları üzerinde durulduktan sonra, metin, arketipler ekseninde değerlendirilmiştir. Su kültü etrafında oluşan folklorik unsurların, metnin dokusuna nasıl yerleştirildiği tespit edilip yorumlanmaya çalı̧̧1mıştır.
\end{abstract}

Anahtar sözcükler: Modern anlatı, masal, arketip, su kültü, yeniden doğuş

u kâinatı oluşturan dört ana unsurdan (anâsır-1 erbaa) biridir. Kutsal metinlerde ve mitik anlatılarda çoğunlukla kutsal bir anlam yüklenen su, daha çok hayat kaynağı, can pınarı, âb-1 hayat olarak olumlu anlam taşımakla birlikte, onun öldürücü ve yok edici özelliğine vurgu yapan olumsuz anlamda kullanımları da vardır. Sümerler'den Amerika yerlilerine, Antikçağ Yunan fel-

* Doç. Dr., Marmara Üniversitesi, Türk Dili ve Edebiyatı Bölümü/İSTANBUL

E-posta: mgunes@marmara.edu.tr 
sefesinden İslam dinine kadar bütün uygarlıklarda kâinatın özünün su olduğuna inanılır. İnançlardaki bu varsayım Kur'an-1 Kerim'de “[b]ütün canlıların özü su'dur" şeklinde ifade edilmiştir (Nur Suresi, 45.ayet). İslam inancında temizliğin önemi birçok ayet ve hadiste vurgulanır; "temizlik imandan gelir" sözü de bu bağlamdaki en yaygın hadistir. Temizliğe verilen önem dolayısıyla İslamî kültürde su, önemli bir yer tutar. Antikçağ Yunan düşünürü Thales "her şeyin başı, kökü, kaynağı su'dur" demiştir. Çağdaş bilim bu inançsal varsayımları doğrulamaktadır (Hançerlioğlu 1993: 469). Yine belirtmek gerekir ki, Hızır inancı da su kültüyle ilgili inanışlarda önemli bir figürdür.

İlk madde olan su, hayatla ölümü birleştirdiği için folklorik anlatılarda hem "âb-1 hayat" hem de "ölüm suyu" olarak geçer. Türeyiş mitlerinde de "insanın bir katre sudan türemesi” bilgisi korunmuştur (Bayat 2007: 248). Su için "potansiyel ve üretken güçleri temsil eden", "varoluşun kaynağı", "dünyanın temeli”, "bitkilerin özü”, "ölümsüzlük iksiri” ifadelerini kullanan Mircae Eliade, suyun önem ve işlevini şu şekilde açıklar: "Potansiyel gücün ve ayrışmamışl1ğın ilkesi, her tür kozmik tezahürün temeli, bütün tohumların taşıyıcısı olan su, bütün biçimlerin kaynaklandığı ve bir felaket ya da kendi gerilemeleri sonucunda dönecekleri ilk özü simgeler. Başlangıçta ve her tür tarihsel ya da kozmik döngünün sonunda su vardır ve her zaman var olacaktır"(2009: 196).

Türk topluluklarında su her çağda mukaddes tutulmuştur. Bu gelenek etrafında "mukaddes su", "ebedî su" (âb-1 hayat), "arı su" vb. kavramlar, birçok inanç, atasözü ve deyim oluşturmuştur (Ögel 1995: 326-331). İslamiyet'in kabulünden önce ve sonra -bazı değişimler olmasına karşın- Türkler arasında, su kültüyle ilgili birçok inanç ve uygulama var olup bu kült, "yer su" inancının uzantısı olarak değişik şekil ve kisveler altında hâlâ varlığını sürdürmektedir (Çobanoğlu 1993: 297).

Türk kültüründe "yer-su" inanışları bağlamında toprak ve su yan yana anılır. Toprak, canlıları içinde barındırıp besleyen yaşama mekânı, su ise hayat iksiri olarak görülür. Su, başka topluluklarda da geçmişten bugüne "yer-su" inanışları etrafında çeşitli kültlere konu olur (Oymak 2010: 36). Türk halk inanışında ve kültüründe göl, çay, akarsu, pınar gibi su kaynakları etrafında kült ve efsaneler oluşur. Oğuz Kağan, Türeyiş, Şu gibi birçok Türk destanında su, motif ve kült olarak geçer (Aslan 2007: 89-96). Bazı Türk destanlarında kutsal atların mekânı su altları olup "destan kahramanlarının atları çoğunlukla göl, deniz ve gökle ilişkili olağanüstü bir kökenden gelmiş olarak kabul edilirler" (Çobanoğlu 2003: 110). Dede Korkut Hikâyeleri’nde de su kültüyle ilgili inanı̧ ve uygulamalara farklı biçimlerde rastlanır (Korkmaz 1998: 91-98). Türk dünyası masallarında da su kültü etrafında oluşan birçok motif vardır (Türkan 2012: 135-148). 
Modern Türk şiirinde ve anlatılarında da suyun, motif olarak metnin kurgusunda işlevsel olarak kullanıldığına rastlanır. Örneğin Yahya Kemal'in "Açık Deniz", "Sessiz Gemi”, "Ses" vb. şiirlerinde su, sembolik açılımları olan bir unsurdur. Yine 1şı ve suyun Ahmet Hamdi Tanpınar'ın estetiğinin kurucu unsurları olduğunu belirtmek gerekir (Kahraman 2000: 12). Mustafa Kutlu'nun Beyhude Ömrüm hikâyesinde ise su motifi, kurguda oldukça işlevseldir. Hikâyede yağmur, bulut vb. suyla ilgili unsurlar da motif/izlek olarak geçer. Suyun hayat verdiği tabiat, kahramanı hayata bağlamakta, kahraman hayatını suyla yeniden doğan bahçesine adamaktadır. Hedefini belirleyen kahraman, önüne çıkacak engellere karşı hazırlıklı, nasıl bir tepkiyle karşılaşacağını tahmin etmektedir. Bereketli suların çıkarıldığı "Islak Kaya” ne köylülerin ne de Yadigâr'ın ${ }^{1}$ gözünde kutsal değildir. Ancak Islak Kaya’nın öneminin fark edilmesiyle -bir bakıma onun keşfedilmesiyle- kaderine terk edilen, işlevsizleşen kıraç topraklar yeniden canlanıp, etrafinda bahçe oluşturularak burada çok değerli ürünler yetiştirilir.

\section{Beyhude Ömrüm Hikâyesinde Geleneksel Anlatılara Özgü Unsurlar}

Geleneksel anlatılarda, masallardaki kalıpların birçoğunu eserin içinde görmek mümkündür. Bu anlatılara özgü bazı anlatım unsurlarının ve motiflerin kullanıldı̆̆ Beyhude Ömrüm hikâyesinde, kahramanın Islak Kaya'yı parçalamak ya da suyu bulmak için verdiği mücadelenin aşamalarına bakıldığında, Propp'un "kişilerin işlevleri"ne ilişkin sıraladığı kalıplardan bazılarıyla benzerlik gösterdiği görülür. Masallarda kahramana "büyülü bir nesne gösterilir", Yadigâr da büyülü nesne olan suya ulaşmak için yine büyülü nesne olarak nitelendirilmeye uygun olan Islak Kaya’yı fark eder. Yadigâr, Islak Kaya'yı yarmayı planlayınca, ona kılavuzluk eden Berber Hacı ve Deli Derviş yardımına koşarlar. Masallarda "kahraman özel bir işaret edinir" (Propp 1985: 57-67); kendine özgü yöntemleri olan Yadigâr da "güç bir iş" olan Islak Kaya'yı yarmayı başararak kıraç toprakları yeşertir. Yine Yadigâr, masal kahramanları gibi arama eylemine girişir. Yardımcıları/destekleyicilerin telkinleriyle daha çok güdülenir. Yadigâr "bir küçük rüyanın peşindeki 'sessiz adam'dır” (Demir 2011: 40).

Beyhude Ömrüm hikâyesinde kahramanın sonlu yolculuğu, Lord Raglan’ın "geleneksel kahraman"(1998: 126-138) kalıbıyla az da olsa benzerlik gösterir. Her ne kadar masallardaki gibi kral ya da vahşi hayvanlara karşı olmasa da, kahramanın Muhtar Halil ile mücadelesi, karşıt güce karşı bir erginleşme süreci yaşaması, uzun uğraş sonucu Islak Kaya'yı dinamitle patlatması, zaferinin kendisiyle sınırlı kalıp oğlu tarafından devam ettirilmemesi gibi motifler bakımından geleneksel kalıplara uymaktadır. Yadigâr'ın eylemleri, Greimas'ın

1 Hikâyede kahramanın adı belirtilmez, ancak babasının arkadaşı Berber Hacı onu emanet/yadigâr olarak gördüğü için onu hep "Yadigâr" diye çağırmıştır. Bu nedenle bu yazıda da kahramandan Yadigâr olarak söz edilmiştir. 
"eyleyenler" kalıbına uyarlandığında onun amacını gerçekleştirmek için "gerekli edinci kazan"dığı, Islak Kaya'yı yararak "gerekli eylemi başar” dığı, kurduğu bahçesinde yetişen ürünlerin çok beğenilmesiyle de "onurlandırıcı deneyim"den geçtiği görülür (Yücel 2008: 208).

Beyhude Ömrüm hikâyesinin kurgusunda İslamî Türk halk anlatılarında olduğu gibi dinî motifler de işlevseldir. Örneğin Yadigâr, eylemini gerçekleştirmeye duayla başlar, işe başladığında ilk olarak Deli Derviş’le karşılaşmasını hayra yorar. İlk karşılaşılan kişinin işin hayırlı, uğurlu olmasında etkili olacağı inanc1, Anadolu halkı arasında yaygındır. Yine Islak Kaya'nın içinden su "fıskiye gibi fışkırdı̆̆ı" zaman kıbleye dönüp Allah'a şükreder, abdest alıp iki rekât namaz k1lar (Kutlu 2001: 81).

Masalsı anlatılarla arasındaki benzerlik kısaca bu şekilde açıklandıktan sonra belirtmek gerekir ki Beyhude Ömrüm, her ne kadar geleneksel türün birkaç kalıbını içerse de, o bir masal değil, modern insanı konu alan bir anlatıdır. Her şeyden önce hikâyede olağanüstü hiçbir unsur ya da motif yoktur; kahraman engelleri aklıyla ya da bilge kişilikli modern insanın yardımlarıyla aşar. Birçok geleneksel anlatıda olduğu gibi bu hikâyede de masalsı, mitolojik öğeler işlevsel olup sembolik anlamlar kazanmışlardır. Yazar, hikâyeyi kurgularken halk anlatılarına özgü motiflerden yararlanıp onları birer sembole dönüştürmüştür. Eserin bu özelliği, onu halk anlatılarına yaklaştırdığı gibi ona özgün bir özellik de katar.

\section{Arketipler Ekseninde Beyhude Ömrüm Hikâyesi}

İlk insanlardan miras olan arketipler, ilk ve iç algılama tarzları olup içgüdüseldir, "kişisel deneyimin meyvesi değildir" (Jung 2013: 256). Birbirinden çok farklı ve bağımsız kültürlerde benzer sembollere rastlanması, farklı dönem ve toplumlarda aynı durum karşısında benzer tepkilerin gösterilmesi, arketiplerin içgüdüsel ve ilkselliğiyle ilgilidir. Bir durum karşısında modern insanın verdiği ilk tepkiler, ilkel insanınkinden farksızdır. Ancak modern insanın eylem biçimi ve hedefe ulaşma yollarında yöntemsel değişiklik, çağa özgülük hemen dikkat çeker. Bazı modern anlatılar, arketipler ekseninde okunmaya müsaittir. Beyhude Ömrüm hikâyesinde kahramanın suyu bulmak için verdiği mücadele "arama" arketipini, suyla kıraç toprakların canlanması da "yeniden doğuş” arketipini, bahçenin uzun ömürlü olamayışı karşısında Yadigâr'ın tutumu ise "teslimiyet" arketipini simgeler.

\subsection{Arama Arketipi: Suyun Ardında Bir İdeal Yolcusu}

Çeşitli kültürlerdeki masallara bakıldı̆̆ında yola çıkan kahramanların birçok engellerle karşılaşıp doğaüstü insan ya da hayvanlardan yardım aldığı, 
sonunda istediğini elde edip geri döndüğü görülür. Ana çizgileriyle aktarılan bu durum "arama arketipi”dir. Bu arketip, sadece masallarda değil mitoslarda, eposlarda, Ortaçağ romanslarında, modern romanlarda da bulunur (Moran 1994: 201). Belirtmek gerekir ki, ne Beybude Ömrüm adlı eser masaldır, ne de Yadigâr olarak adlandırılan kişi masal kahramanıdır. Ancak bazı yönleriyle masal kahramanlarını andıran hikâye kişisinin "büyülü nesne" olan suyun ardındaki mücadelesi, "arama arketipi”ni ve bunun etrafında oluşan motifleri andırır. Yadigâr da destan ya da masal kahramanları gibi hedef belirler, buna ulaşmak için bazı hazırlıklar yapar, yola çıkar; bu süreçte bazı engellerle karşılaşıp onlarla mücadele eder ve sonunda zafer kazanıp hedefine ulaşır. Hikâyedeki kahraman, hedefine ulaşmak için olağanüstü bir güce ya da desteğe ihtiyaç duymaz. Berber Hacı ve Deli Derviş gibi gönüllü yardımcıları olur. Büyük emek sarf ederek engelleri aşar, hedefini gerçekleştirir. Islak Kaya'nın altında su olduğundan emin olunca planını yapmaya başlar. Kayayı yarıp "miri malı" olan bu arazideki otlarla taşları ayıklayıp orayı çitlerle çevirir; buz gibi soğuk suyu kullanır. Böylece kıraçlaşan toprak yeniden canlanır ve işlevine uygun olarak doğurganlaşır.

Islak Kaya'nın varlığından yıllardır haberdar olunmasına karşın bir gün kaya, Yadigâr'a çok farklı görünür; aralarında masalsı bir etkileşim olur, adeta ona "Beni keşfet, beni değerlendir!" der. Yadigâr bu durumu şu şekilde ifade eder:

Birden 1slak kayayı görüverdim.

Birden deyişim lafin gelişi, 1slak kaya orada ben bildim bileli var.

Var ama bu defa görüşüm başka.

[...]

Yahu bu kayada ne var?

$\mathrm{Ne}$ oldu şimdi bana?

Kaya tarlanın alt başındaki derenin öteki yakasında. Üzerinden eksilmeyen 1slaklığı, yeşil yosunları, kenarından köşesinden firlamış otları, ısırganları, dikenleri dibinde veya bir yerlerinde mutlaka su olduğunu fisildayip duruyor.

Su..

Evet bu kayanın dibinde su var, kesin var.

Peki beni böyle heyecanlandırıp yüreğimi gümbürdeten bu mu yani.

$\mathrm{Bu}$ kayanın dibinde su olduğu hep söylenmiştir. Bütün köy halkı bilir bunu.

$[\ldots]$

Sonunda derdimin ıslak kaya değil de onun önündeki çalılar, kayadan kopup gelmiş iri çalılar, kayadan kopup kalmış iri taşlarla dolu iki evleklik avuç içi kadar arazi olduğunu anllyorum. (2001: 10-11)

Yadigâr, zaman zaman "[e]kini-harmanı bırakıp, ben buraya bahçe kuracağım diye koca kayayı devirmeye kalkışmak akıl işi mi?” (2001: 20) diye düşünüp tedirgin olsa da gölge arketipinin "ilginç çekimine kapılma tehlikesine göğüs 
gerer”, "ürkütücü veya güçlü yönüyle birlikte yaşamayı öğrenir” (Fordham 2011: 104). Makul hareket eden Yadigâr, nasıl engellerle karşılaşacağını da tahmin eder. Örneğin köyün kıskanç muhtarının haksız baskılarını ve iftiralarını, Islak Kaya’nın etrafında tarlası olanların şüphelenme olasılıklarını göz önünde bulundurur. Eylemi yasal olduğu için hiç endişe etmez ve yılmaz.

Yadigâr'ın yaşadığı çatışmalar da mitik ya da masalsı anlatılardaki “ideal sonsuz yolculuğa çıkan kahraman”ların yaşadığı tedirginliklere benzer. O da kısa süreli bir tedirginlik yaşasa da eylemini gerçekleştirmekte kararlı davranır. Özellikle de oluşturacağı bahçenin "yedi köy” tarafindan "parmakla gösterileceği”, takdir edileceği hayali onu daha da şevklendirir. Eşi ona destek olmakla birlikte zaman zaman emeklerinin boşa gideceğini düşünür. Yasal olarak hiçbir engel olmadığ 1 konusunda ona güvence veren Berber Hacı ise Muhtar Halil ya da başka engelleyicilere karşı ona destek olma sözü verir. Böylece kahraman "kendisini her yerde destekleyen iyi kalpli bir gücü” görür (Campbell 2013: 113). Hacı, kahramanın "amacına ulaşması yolunda kayanın büyüklüğünü yenebilmesine karşı destekleyici bir güç oluşturur” (Altunkaya 2012: 766). Deli Derviş de "Allah nasip eder ise biz de bu bahçenin meyvesinden yeriz art1k" (2001: 37) diyerek ona moral ve cesaret verir. Masallardaki yardımcı, destekleyici kişilere benzeyen Berber Hacı ve Deli Derviş, Yadigâr "isteyimden gerçekleştirime geçtiğinde" ve "eylemini gerçekleştirmek için gerekli güçle donandığında” (Yücel 2008: 149) bilge kişilikleri ve deneyimleriyle onu yönlendirirler. Yadigâr zorda kaldığında hep Deli Derviş'e başvurur ve ondan destek alır. Engelleyici konumdaki Muhtar ise hayatındaki her şeyi hep kolay yollardan elde ettiği ve art niyetli olduğu için Yadigâr'ın eylemini "[o] kıraç kayalıkta bahçe olur mu? Adam bizimle maytap geçiyor" diye yorumlar (2001: 76).

Yadigâr'ın babası Gülpaşa da definecilik işleriyle uğraştığı için onun define ya da maden aradığından şüphelenirler. Onu kayayı yararken ilk gören Çerçi, karşılaştığı kişilere de anlatır. Ancak gündüz vakti define aramanın makul bir davranış olmayacağ1 düşünüldüğünden, maden aradığı tahmini yürütülür. Kimisi ise "karasevda olmuş" diye düşünür. Kayayı el gücüyle parçalayamayıp dinamitle patlatınca söylentiler çeşitlenir: “-Herif ıslak kayayı dinamitlemiş./ -Defineyi bulamayınca ifrit olmuş basmış dinamiti./ -Yok ağa yok, ne definesi. Kayanın altında maden varmış, maden..." (2001: 68). Dinamitle kayanın parçalanması, hedef önündeki büyük engellerden birinin ya da eşiğin aş1masıdır. Kahramanın eylemini gerçekleştirme biçimi, masal kahramanlarının eylemlerini andırsa da hikâye gerçeklik boyutları içinde kurgulandığg için kahramanın doğaüstü bir yardım aldığı söylenemez. O kişisel deneyimleriyle hareket eder, deneyimleriyle olgunlaşır. Hedefine varmak için zihnini işletir; bir de yardımsever ve bilge kişilerin tavsiyesine uyar. 
Hikâyede define ve maden söylentisi, iftira ve kara çalmaya eğilimli olduğu kadar kolay yoldan zengin olmaya alışkın olan halkın bakış açısını yansıtması bakımından önemlidir. Yadigâr için önemli olansa şudur: Islak Kaya’nın parçalanması sonucu elde edilecek su sayesinde tabiat yeşillenecek, kurulan bahçede yetişecek meyveden insanlar kadar kurt kuş da yararlanacaktır. Böylece dünya denilen menzilde konaklayan Yadigâr, hayatında önemli bir işi başaracaktır. Kendi ifadesiyle "[k]arın karşı yatan dağların doruklarına düştüğü, deli poyrazın köyü kenti buz kesmeye başladığı bir gün; 'ikindi ile akşam arasinda' suyu bulur” (2001: 80). Yazar, olay zamanını kesin bir zaman dilimiyle belirtmek yerine "ikindi ile akşam arasında" şeklinde ifade ederek Kur'an-1 Kerim'deki zaman ifadelerini anıştırır.

Islak Kaya'nın yakınındaki tarlalarıyla bile ilgilenmeyen Muhtar'ın, biraz suyun keşfedilmesi üzerine arazinin önem kazanması, biraz da kendisinin varlığının önemsenmemesi dolayısıyla Yadigâr’a düşmanlığı artar. Masallardaki kötücül tipleri simgeleyen Muhtar, engel çıkarıcı ve zulmedici özellikleriyle varlı̆̆ını hissettirir. Yadigâr "[i]zine ne hacet Muhtar, Allah'ın dağı. Sonra suyu da bulduk; sana da yarar, bana da..." (2001: 87) şeklinde soğukkanlı ve makul tepki verse de dik ve onurlu bir duruşa alışkın olmayan Muhtar, tehdit ve şiddete başvurur. Önce bahçeyi yaktırır, Yadigâr'ın aldırmadığını görünce de onu dövdürerek sindirmeye çalışır. Sonra birçok usulsüzlüğe başvurarak mahkemeyle bu bahçeyi özel mülkiyetine geçirmeyi dener. Muhtar engelleyici, Yadigâr ise direniş̧̧idir. Hedefine ulaşmak için her türlü tehlikeyi göze alan Yadigâr yılmaz ve bildiği yolda ilerlemeye devam eder. Öyle ki yatakta baygın yatarken de "[b] ahçe... fidanlar..." diye sayıklar. Bu bağlamda Deli Derviş'in “[ş]u suyu bulmak için gece gündüz ter döken, şu bahçeyi kurup çatan adam benden daha bir derviş" şeklindeki sözü de anlamlıdır (2001: 123). Yadigâr, bu yönüyle de destan ve masal kahramanlarına benzer. Baskılar onu daha çok kamçılar, karşılaştığı zor engelleri birer birer aşar, hedefine doğru ilerler. Sonunda Berber Hacı'nın da yönlendirmeleriyle bahçeyi üretken hâle getirmeyi başarır. "Büyülü yardımcı"ya da örnek oluşturan Berber Hacı ve Deli Derviş bazı yönleriyle yüce kişi arketipini de temsil ederler (Propp 1985: 88). Onlar, Yadigâr'a hep olumlu ve doğruyu gösterir ve fayda sağlayacak eyleme destek olurlar.

\subsection{Bereketli Sular ve Yeniden Doğuş Arketipi}

Eski Türklerde yerden kaynayan sular, mukaddes kabul edilir (Ögel 1995: 357). Geleneksel toplumlarda, özellikle kıraç toprakların çoğunluğu oluşturduğu yerleşim yerlerinde, suyun bulunduğu alanlara kutsal özellikler yüklenir. Beybude Ömrüm'de olay her ne kadar modern dönemde geçse de Yadigâr'ın yaşadığ1 köyde geleneksel ve tabiata bağlı bir hayat sürülmektedir. Bu tür coğrafyalarda su, en önemli hayat kaynağı ve can damarıdır. Toprağa bağlı, ta- 
biatı koruyarak işleyip doğurganlaştırmaktan büyük mutluluk duyan Yadigâr için Islak Kaya kutsal olmasa da çok özel bir anlam ifade eder. Islak Kaya'nın keşfedilip etrafindaki kıraç toprakların verimli hâle getirilmesi, yeniden doğuş arketipini simgeler. Kayanın etrafındaki topraklar susuz kalınca ölgünleşmiş, suyla temas edince de dirilip yeniden doğmuştur. ${ }^{2}$ Jung'a göre ölüm gibi yeniden doğuş da doğanın isteğidir (2003: 62). Bu bağlamda Eliade'nin şu yaklaşımı da çarpıcıdır: "Suyla temas etmek, her zaman yenilenmeyi temsil eder; çünkü eriyip giden daha sonra 'yeniden doğacaktır'; suya batış, yaşamın ve yaratıcılı̆̆ın potansiyelini çoğaltır ve geliştirir” (2009: 196).

Geleneksel toplumlarda kutsal anlamlar yüklenen pınarların her biri, farklı şifa kaynağı olarak görülüp üremeyi, bolluk ve bereketi simgelerler. Keşfedilen kaynaklar sayesinde tabiat canlanır, yeniden doğar. "Su hayat verici bir başlangıç olarak mitolojik düşüncede ana rahminin bir sembolüdür” (Beydili 2005: 502). Her ne kadar mitolojilerde suya anaç özellik yüklense de bu hikâyede daha çok baba işlevi üstlendiği görülür. ${ }^{3}$ Bachelard'ın ifadesiyle "[k]arışım su ve toprak gibi dişil eğilimli iki madde arasında olursa, pek tabii olarak, içlerinden biri, eşine 'egemen olmak' için hafifçe erilleşir" (2006: 111). İki unsurun birleşiminde, toprak anne, su baba ${ }^{4}$ olup bahçe ve üretilen meyve ve sebzeler de çocukları simgeler. Birçok inanış sisteminde toprak anneyi sembolize eder: "Yerden çıkan her şey yaşam doludur ve yere dönen her şey yeniden yaşam bulur" (Eliade 2009: 255). Böylece toprak sıradan bir kara parçası olmaktan çok canlılar için en önemli hayat kaynağı olur. Su ise onun can damarıdır. İçinde şifalı suyu gizlemesi ve bunun hayat kaynağı olması vb. özellikleriyle Islak Kaya, anne karnını da simgeler. Kayadan su çıkar ve bu sayede üreme gerçekleşir. Berber Hacı'nın yönlendirme ve destekleriyle Yadigâr'ın bahçesi yeşillenir, birçok meyve ve sebze yetişir. Kayanın suyu, kıraç topraklar için hayat kaynağı olur. Masallarda suyun ölüleri diriltmesi gibi, zaman içinde bakımsızlık dolayısıyla ölgünleşen kıraç topraklar da Islak

\footnotetext{
Mustafa Kutlu'nun Tufandan Önce hikâyesinde de kasabanın biraz dişında Otbitmez Tepesi'ne yerleşen göçerler, kuytuda kalan suyu yerleşim yerine getirirler. Böylece hem içecek su ihtiyaçlarını karşılarlar hem de yıllardır ekilmediği için ölgünleşen kıraç toprakları canlandırırlar (2003: 96-98). Yine yazarın Zafer yahut Hiç hikâyesinde de suyun keşfedilmesi üzerine Tepeköy kurulur; suyun ayağını bir kazma ile aşağıya indiren köylüler, bahçe bostan yapıp kendilerine yetecek kadar meyve ve sebze yetiştirirler (2012: 12).

3 Türk folkloründeki sudan evlat edinme inancında da suya baba işlevi yüklendiği görülür. Örneğin, Anadolu yörüklerinde kısır kadınlar, nisan yağmurlarının suyundan içip çocuk sahibi olacaklarına inanırlar. Azerbaycan'da da kısır kadınlar, hamile kalabilmek için mağaralara gidip tavandan damlayan suyu toplayıp içerler, zeminle duvar arasından akan suyu da karınlarına sürerler. Bu şekilde doğan çocuğu suyun verdiğine inanırlar. Yine genç gelinler Amuderya ırmağının bir sahilinden diğer sahiline geçerek su iyelerinin yardımı sayesinde çocuk sahibi olacaklarına inanırlar (Beydili 2005: 502).

4 Eski Mısır'da da Nil nehrinin suları erkek, tarıma elverişli toprakları da dişidir; Yunan'da da nehirler erkektir. (Rudhart 2006: 132)
} 
Kaya'nın sularıyla dirilir ve fidanlarla yeşererek güzelleşir. Islak Kaya'nın suları iksir işlevi görür ve hasta toprakları tedavi eder. ${ }^{5}$

Bilge kişiliğiyle öne çıkan, Yadigâr'ın yönlendiricisi konumundaki Berber Hacı, meyvelerin de sırrını bilir. Bu nedenle bahçeye uygun olmak şartıyla, her bir meyvenin en kalitelisini bulup yetiştirirler. Soğuğa dayanıksı olduğu için Malatya kayısısı değil de yörenin ekşi kayısılarından yetiştirirler, armut fidanları da yakın köyden tedarik edilir. Bilge ya da arif bir kişi olan Berber Hacı'ya göre Amasya, Niğde, Eğirdir elmalarının meşhur olmasına karşın en kaliteli elma, Erzincan'da Hah; üzüm ise Cicim köyündedir. O nedenle bunlar da o köylerden tedarik edilir. Fidanlar, Hacı'nın tavsiyesine göre bahçenin uygun yerlerine dikilir.

"Türkler suyu kuvvet ve bereket kaynağı kabul ettikleri gibi kahredici ve koruyucu Tanrı da sayarlar” (Uraz 1967: 132). Kutsal inançlarda ve mitolojilerde, başta Nuh Tufanı olmak üzere su kahredici özelliğiyle de geçer. Beyhude Ömrüm'de Yadigâr'ın bahçesini Kanlı Dere'nin yıkıcı sel sularına karşı koruma mücadelesine bakıldığında, suyun kahredici yönüyle öne çıktığı görülür. Kanlı Dere Dede Korkut Hikâyeleri’ndeki kanlı suyu hatırlatır. Yazar, anıştırma yöntemiyle Nuh Tufanı kıssasına ve Dede Korkut Hikâyelerìne göndermede bulunmaktadır. Kutlu'nun Tufandan Önce hikâyesinde de Deli Dere'nin sular1 yıkıcı yönüyle kendisini göstererek tufana neden olur. Anadolu'nun birçok yöresindeki dereler, uzun aralıklarla da olsa felakete neden olmaktadır. Bu tür hadiseler üzerine Çarşambayı Sel Aldı gibi birçok türkü ve ağıt yakılmıştır.

Beyhude Ömrüm'de bahçesini de bir evlat gibi gören Yadigâr ve oğlu bahçedeki ağaçları kurtarmak için çetin mücadele verirler. Toprağa hizmeti, doğayı korumayı "gönül" işi olarak gören Yadigâr, biraz maddî hasar olsa da sel ile mücadele etmeyi başarır. Sel ile baş etmenin zor olduğunu fark eden Yadigâr ve oğlu, "edinç" kazanırlar.

\subsection{Teslimiyet Arketipi: Suya Giden Emek}

Geçmişten bugüne su kültü etrafında birçok efsane anlatılmış, birçok deyim ve atasözü oluşmuştur. Daha önce de belirtildiği üzere Türk kültüründe suyla ilgili olumlu sembol ya da imajlarla birlikte olumsuz çağrışımlara yol açan söylence ve sözler de oluşmuştur. "Suya düşmek", "suya gitmek", "suya vermek" vb. deyimler olumsuz durumlar için kullanılmıştır. Hikâyede büyük umut ve hayallerle Islak Kaya'yı parçalayıp ölgünleşmiş tabiatı canlandıran kahramanın hayalleri ve idealleri de zamanla suya gidecektir. Kader karşı-

\footnotetext{
Suyun tedavi etmesi ve iksir etkisi yapması motifi, Türk dünyası masallarında da geçer. Örneğin, Keloğlan'ın kutsal özelliği olan bir pınarda yıkandıktan sonra kafasında saçların bitişi gibi. (Türkan 2012: 143)
} 
sında teslimiyetten başka çaresi olmadığının bilincinde olan Yadigâr, dünya denilen menzilde konaklayıp kendine özgü bir bahçe oluşturduktan sonra hakikati kabullenip Allah'a teslim olacaktır.

Yadigâr'ın fidanları olgunlaşınca bahçenin ünü de yayılır, uzak köylerden bile ondan meyve almaya gelenler olur. Onun için bahçe ve meyve üretimi ticaret değil, gönül işi olduğundan, meyvelerin çoğu yoksul köylülere dağıtılır. Yadigâr nar ve üzüm yetiştirmek için emek harcar, ancak bu hedefini gerçekleştiremediği için üzülür:

Ne yaptımsa tutturamadım mübareği. Ama vazgeçmiş değilim. Ömrüm oldukça bu bahçeye nar dikmeye devam edeceğim. Sonunda biri tutacak elbet. Böylesi bir bahçe narsız olur mu? (2001: 146).

Üzüm de geçti aklımdan ya; şöyle bir yokladım pek bir şey bulamadım. Zaten buraya uygun asma yetiştiremedik. Ne kadar denedimse de şöyle göze görünür bir cins tutturamadı.

Üzüm bir, nar iki.

İkisi de olmadi. (2001: 175)

Fars mitolojisinde en kutsal meyvelerden sayılan nara, Tevrat ve Kur'an-1 Kerim'de de göndermeler vardır. Yunan mitolojisinde de nar ağacı verimlilik, üretkenlik ve bolluğun simgesidir (Yıldırım 2008: 285). Bu bağlamda yorumlandığında Yadigâr'ın bahçesinde birçok meyveyi yetiştirmesine karşın nar yetiştirememesi, Islak Kaya’nın etrafindaki bahçenin zamanla üretkenliğini kaybedeceğinin; bahçenin uzun ömürlü olamayıp doğurganlığını devam ettiremeyeceğinin bir işaretidir. Yadigâr hayattayken çok doğurgan olan bu bahçe, ondan sonra verimini yitirecektir. Ekonomik ve sosyal nedenlerle Yadigâr'ın oğlu da köydeki birçok kişi gibi İstanbul'a göçerek toprağı terk edecektir. Böylece Yadigâr'ın soyundan kimse toprağa emek vermeyecektir. ${ }^{6}$ Yadigâr'’n bahçeye uygun üzüm asması bulamaması da dikkate değerdir. Fars mitolojisinde üzüm, mutluluk ve neşe kaynağı olarak görülür (Bayat 2008: 286). Bu bağlamda düşünüldüğünde bahçede üzüm yetişmemesi, Yadigâr'ın mutluluğunun kısa süreli olacağının işaretidir. Bazı efsanelerde üzüm bereketin sembolü olarak geçer (Şenocak 2007: 168). Kısa süre içinde bereketli bir toprağa dönüşen bu bahçe, üzüm yetişmediği için doğurganlığını devam ettiremeyecektir. Üzüm ve narın yetiştirilememesi, insanoğlunun hayattaki bütün arzularına ulaşamayacağı gerçeğiyle de ilişkilidir.

Biraz yaşlandığı, biraz da yılın büyük çoğunluğunu İstanbul'da geçirdiği için birkaç yıl bahçeyi işleyememesi, Yadigâr'ı üzer. Her ne kadar Deli Derviş bahçeyle ilgilenmeye çalışsa da bu yeterli olmaz. Bahçeyi evladı gibi gören,

\footnotetext{
Ercan Yıldırım da Yadigâr'ın nar yetiştiremeyişinin içinde "ukde” olarak kalmasını, "insanın eksik yaratılışlı olduğunun kanıtı”, gerçekleştirilmesi başarılamayan istekler olarak yorumlar. (2007: 120) Farklı yorumlara müsait olan bu hikâyede narın bu bağlamda da düşünülmesi olasıdır.
} 
ondaki fidanların kurumasını bir neslin sönmesi gibi düşünen kahraman, İstanbul'dayken sürekli köyüne özlem duyar, bahçesini yeniden canlandırmayı hayal eder. Özlem ve hayallerini şu şekilde ifade eder:

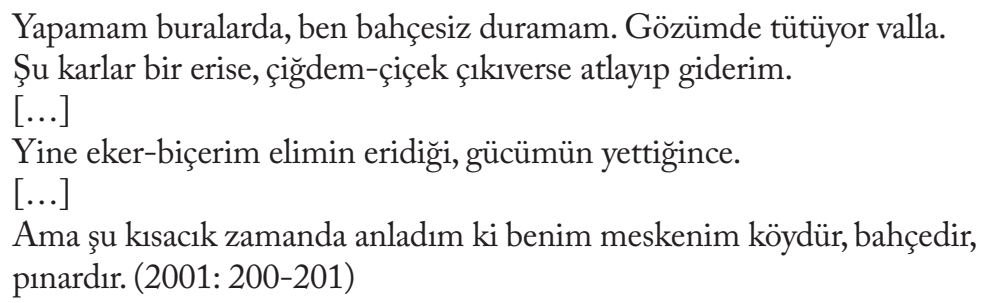

Yadigâr tabiat sevgisini o kadar içselleştirir ki evlatlarından ayrılıp bahçesiyle birlikte yaşamayı tercih eder. Köy ve tabiat özlemi evlat sevgisine baskın gelince İstanbul'dan ayrilır. Deli Derviş ile birlikte güçleri elverdiği kadar bahçeyle ilgilenirler. Yadigâr öldüğünde de mezarının üzerine kar yağmasını, çiçek kokularını hissetmeyi arzular. Yazar, metafizik bir yorumla Yadigâr'ın tabiata sonsuza kadar devam edecek sevgisini gösterir. Sudan yaratılan insanoğlu, sonunda toprakla bütünleşir. Kur'an-1 Kerim'de birçok ayette de vurgulanan dünyanın oyun sahnesi, gündelik hayatın da oyun ve eğlenceden ibaret olduğu imgesi, Kutlu'nun Bu Böyledir, Yoksulluk İ̧̇imizde, Tufandan Önce gibi birçok eserinde geçer. Beyhude Ömrüm'de de önce sevdiklerini ve yakınlarını kaybeden, sonra da kendisi ölen Yadigâr'ın şahsında dünyanın oyun sahnesinden ibaret olduğu ve Yadigâr'ın da herkes gibi oyunla oyalandığı imlenir. Yadigâr, "[d]ünya hayatı bir oyun ve eğlenceden ibaret. İşte geldik gidiyoruz" (2001: 141) sözleriyle dünyanın faniliğini vurgular. Yazar, Kur’an-1 Kerim’de dünyanın bir oyun alanı ve fani olduğunu belirten birçok ayete göndermede bulunur (En'am 32, Ankebut 64, Kasas 60 vb.). Hikâyede "leitmotiv" olarak geçen Akpınar'in da su kültü etrafinda vurgulanması gerekir. Akpınar'in başındaki "ak" sıfatı saflığ1 ve temizliği simgeler. Yıllardır, köyün üst tarafinda bulunan bu pınardan binbir güçlükle testilerle su taşıyan köylüler, elbirliği edip pınarın suyunu köye getirmezler. Zaman içinde köyde birçok kişinin zenginleşmesine rağmen kimsenin böylesine değerli bir kaynağı değerlendirememesi, Yadigâr' 1 üzer. ${ }^{7}$ Akpınar bereketin simgesidir, onun suyunun evlere getirilmesi demek viran olmaya yüz tutan köyün yeniden canlanması demektir. Ne var ki suyun köye taşınamaması, köyün viraneye döneceğinin işaretidir.

\footnotetext{
Kutlu'nun suyun hayat kaynağı oluşunu vurguladığ1 "Su Sesi” hikâyesinde, berber çırağ1 Cevat fakirliğine rağmen çeşmenin çalınan kurnasını sürekli yeniler. Geceleri çeşmeyi kontrol eden Cevat, onun etrafinı temizler, yalağında biriken su ile mescidin bahçesindeki ağaçları sular. Cevat böylece halkın duasını almaya çalışır. (2013: 18-20)
} 


\section{Sonuç}

Geçmişten bugüne Türk kültüründe olduğu kadar evrensel kültürde de önemli yer tutan, etrafında birçok inanış oluşan, sembolik açılımları olan su kültünün izleri, modern bir anlatı olan Beyhude Ömrüm hikâyesinin kurgusunda ve ritmik oluşumunda da yansıma alanı bulmuştur. Kurgu ve motifler bakımından masalsı anlatılarla benzerlik gösteren Beybude Ömrüm'de su kültü etrafinda oluşan birçok folklorik ve sembolik unsur, metnin dokusuna ustaca yerleştirilmiştir. Örneğin, hep Yadigâr'ın yanında olup ona destek olan, moral veren Deli Derviş ve Berber Hacı destanlardaki bilge kişileri andırırken, köy muhtarı da masallardaki kötücül unsurları andırır. Kahramanın büyülü nesne olarak nitelendirilebilecek suyun ardındaki mücadelesi "arama arketipi", ölgünleşmiş tabiatın su sayesinde canlanıp doğurganlaşması da "yeniden doğuş arketipi” etrafında yorumlanabilir. Islak Kaya’dan çıkardığı su sayesinde tabiatı canlandırıp güzelleştiren Yadigâr'ın ruhu da, başarısının verdiği hazla, canlanır ve özgüveni tazelenir.

Hikâyede Yadigâr'ın eylemi örneğinde metinlerarasılık tekniğiyle dünyanın faniliği ve oyun sahnesinden ibaret oluşuna göndermede bulunulur. İnsan ömrünün de su gibi akıp gittiğini vurgulayan yazar, eserin sonunda su ile ömür arasındaki ilişkiyi gösterir. Hayatını suya adayan Yadigâr'ın emekleri, daha o yaşarken suya gitmeye başlar. $O$, öldükten sonra mezarının üzerine karlar yağması da ruh ve su ilişkisi bağlamında anlamlıdır. Ölümle birlikte, kahramanın yolculuğu sona erer. Yazar, Yadigâr öldükten sonra onun tabiat sevgisini ve suya bağllliğını devam ettirerek, onu tabiatla iç içe göstermiş, dolayısıyla ölümüne metafizik bir boyut kazandırmıştır. Yadigâr ölünce simgesel olarak toprak olur, üzerine yağmur ve kar yağgdı̆̆ için su ve toprak bileşimi kurulur. Böylece Yadigâr'ın ruhu sonsuzluğa kavuşmuş, simgesel ebedi dönüş de gerçekleşmiş olur. Burada ölüm yok oluş değil, yeniden doğuş ya da Allah'a kavuşmadır. 


\section{Kaynaklar}

Altunkaya, Hatice (2012). “Beyhude Ömrüm Adlı Hikâyenin Greimas'in Eyleyenler Modeline Göre İncelenmesi”, Turkish Studies 7/4, s.761-771.

Aslan, Ferhat (2007). “Türk Destanlarında 'Su’ Motif”, Türk Kültüründe Su, Haz. İbrahim Akış ve Ferhat Aslan, İstanbul: Manavgat Belediyesi Kültür Yayınlar1, s.75-97.

Bachelard, Gaston (2006). Su ve Düşler, Çev. Olcay Kunal, İstanbul: Yapı Kredi Yay1nlari.

Bayat, Fuzuli (2007). Türk Mitolojik Sistemi, C.2, İstanbul: Ötüken Yayınları.

Beydili, Celal (2004). Türk Mitolojisi Ansiklopedik Sözlük, Çev. Eren Ercan, Ankara: Yurt Kitap Yayin.

Campbell, Joseph (2013). Kahramanın Sonsuz Yolculuğu, Çev. Sabri Gürses, İstanbul: Kabalc1 Yayınları.

Çobanoğlu, Özkul (1993). “Türk Kültür Tarihinde Su Kültü”, Türk Kültürü 31/361, s.288-297.

(2003). Türk Dünyası Epik Destan Geleneği, Ankara: Akçă̆ Yayınları.

Demir, Yavuz (2011). “Beyhude Ömrüm: Çavuş Ăga'nın Zerdalileri/Kör Mustafa'nın Karanfilleri”, Hayat Böyledir Isste Fakat Hikâye, Ankara: Hece Yayınları, s.3944.

Eliade, Mircea (2009). Dinler Taribine Giriş, Çev. Lale Arslan, İstanbul: Kabalcı Yay1nlari.

Fordham, Frieda (2011). Jung Psikolojisinin Ana Hatları, Çev. Aslan Yalçıner, İstanbul: Say Yayınları.

Hançerlioğlu, Orhan (1993). Dünya İnançları Sözlüğ̈̈: Dinler-Mezhepler-TarikatlarEfsaneler, İstanbul: Remzi Kitabevi.

Jung, Carl Gustav (2003). Dört Arketip, Çev. Zehra Aksu Y1lmazer, İstanbul: Metis Yayınları.

(2013). İnsan Ruhuna Yöneliş, Çev. Engin Büyükinal, İstanbul: Say Yayınları.

Kahraman, Hasan Bülent (2000). "Yitirilmemiş Zamanın Ardında: Ahmet Hamdi Tanpınar ve Muhafazakâr Modernliğin Estetik Düzlemi”, Doğu Batı 11, s.9-43.

Korkmaz, Ramazan (1998). “Dede Korkut Hikâyeleri'ndeki Su Kültünün Mitik Yorumu”, Türk Kültürü 36/418, s.91-98.

Kutlu, Mustafa (2001). Beyhude Ömrüm, İstanbul: Dergâh Yayınları.

_ (2003). Tufandan Önce, İstanbul: Dergâh Yayınları.

- (2012). Zafer yahut Hiç, İstanbul: Dergâh Yayınları.

(2013). "Su Sesi”, Hüzün ve Tesadüf, İstanbul: Dergâh Yayınları, s.18-20.

Moran, Berna (1994). Edebiyat Kuramları ve Eleştiri, İstanbul: Cem Yayınevi.

Oymak, İskender (2010). “Anadolu'da Su Kültünün İzleri”, Firat Üniversitesi İlabiyat Fakültesi Dergisi 15/1, s.35-55.

Ögel, Bahaeddin (1995). Türk Mitolojisi: Kaynakları ve Açılamaları ile Destanlar, C.2, Ankara: Türk Tarih Kurumu Yayınları.

Propp, Vladimir (1985). Masalın Biçimbilimi, Çev. Mehmet Rifat ve Sema Rifat, İstanbul: Bilim/Felsefe/Sanat Yayınları.

Rudhart, Jean (2006). "Su”, Çev. Âdem Koç, Millî Folklor 70, s.125-135. 
Raglan, Lord (1998). “Geleneksel Kahraman”, Çev. Metin Ekici, Millî Foklor 37, s.126-138.

Şenocak, Ebru (2007). “Türk Halk Kültüründe ve Mitolojik Bağlamda Üzümün Yeri”, Milli Folklor 76, s.164-172.

Türkan, Kadriye (2012). “Türk Dünyası Masallarında Su Kültü”, Millî Folklor 93, s.135-148.

Yıldırım, Ercan (2007). Mustafa Kutlu Hikâyeciliği: Varoluş Yabancılaşma Hakikat, Ankara: Ebabil Yayıncilik.

Yıldırım, Nimet (2008). Fars Mitolojisi Sözlüğ̈̈, İstanbul: Kabalcı Yayınları.

Yücel, Tahsin (2008). Yapısalcılık, İstanbul: Can Yayınları. 


\section{ABSTRACT \\ The Travel of the Protagonist in Search of Water in Story Beyhude Ömrüm}

Water cult has been existed since ancient time periods and it is based on "ground-water" belief. As the basic motif, beliefs and practices associated with cult have been found in oral literature. In modern Turkish narratives, "water" is used as a functional motif/theme in fiction. Water motif in Beyhude Ömrüm, Mustafa Kutlu's story, is fairly functional in the fiction of the text. In the story, the protagonist, along with being aware of the existence of "the wet rock" for years, takes it as aim when he realizes that the rock contains water within. He makes plans in order to reach his aim just like heroes in tales. His act to cleave the wet rock and take out the water inside reminds the travels of tale heroes. He encounters some obstacles, but reaches his aim by the support of guides and using his mind. By realizing the importance of the wet rock, the waste lands, which were left to their fate, are started to be used compatible with their original aim. Folkloric elements in the story Beyhude Ömrüm were not mentioned in previous works on Mustafa Kutlu. Hatice Altunkaya, who has an original study on Beybude Ömrüm, has examined the story only according to the actant model of Greimas. In this paper, after stressing similarities and differences between the acts of the protagonist of Beyhude Ömrüm in search of water, and of tale heroes, the story has been examined in terms of narration and archetypes. It has been determined how the folkloric elements, which are formed around the water cult, were located in texture of the text, and it has been analyzed.

Keywords: Modern narrative, tale, archetype, water cult, rebirth 
